\title{
Detection of human cytomegalovirus DNA in various blood components after liver transplantation
}

\author{
X.Y. Chen ${ }^{1}$, P.F. $\mathrm{Hou}^{2}, \mathrm{~J}^{\mathrm{B}} \mathrm{Bi}^{1}$ and C.M. Ying ${ }^{1}$ \\ ${ }^{1}$ Department of Clinical Laboratory, Ren Ji Hospital, School of Medicine, Shanghai Jiao Tong University, Shanghai, China \\ ${ }^{2}$ Department of Clinical Laboratory, Rushan Hospital, Shandong, China
}

\begin{abstract}
The quantification of human cytomegalovirus (HCMV DNA) by real-time PCR is currently a primary option for laboratory diagnosis of HCMV infection. However, the optimal sample material remains controversial due to the use of different PCR assays. To explore the best blood component for HCMV DNA surveillance after liver transplantation, whole blood (WB), serum $(\mathrm{SE})$, and plasma (PL) specimens were collected simultaneously from targeted patients and examined for HCMV DNA using one commercially available assay. The HCMV DNA-positive rate with WB (16.67\%) was higher than that with either SE or PL $(8.33 \%$, both $\mathrm{P}<0.01)$. Quantitative DNA levels in WB were of greater magnitude than those in SE (WB-SE mean logtransformed difference, 0.99; $95 \% \mathrm{Cl}=0.74-1.25 ; \mathrm{P}<0.0001)$ and $\mathrm{PL}(\mathrm{WB}-\mathrm{PL}$ mean log-transformed difference, 1.37; $95 \% \mathrm{Cl}=1.07-1.66 ; \mathrm{P}<0.0001)$. Dynamic monitoring revealed that HCMV DNA in WB was positive sooner and had higher values for a longer period of time during therapy. With earlier positive detection, higher sensitivity, and yield of greater viral loads, WB compared favorably to SE or PL and hence is recommended as the superior material for HCMV DNA surveillance after liver transplantation. In addition, infant recipients require more intensive monitoring and prophylactic care because of their higher susceptibility to primary HCMV infection.
\end{abstract}

Key words: HCMV DNA; Blood components; Real-time quantitative PCR; Liver transplantation

\section{Introduction}

Human cytomegalovirus (HCMV), a $\beta$-herpesvirus, circulates widely in the human population and causes opportunistic infections. HCMV seroprevalence in Chinese adults can be as high as over $90 \%$ (1). Although the virus is usually latent in immunocompetent individuals and produces few, obvious lesions, it remains a serious threat to immunocompromised patients, contributing to significant morbidity and mortality among transplant recipients $(2,3)$.

For laboratory diagnosis of HCMV infection, real-time fluorescence quantitative (RTFQ) PCR has been a primary tool to determine quantitative DNA loads. However, the optimal blood component for DNA detection is still under discussion. Peripheral blood leukocytes (PBL) have been cited for their high sensitivity (4-7), but there are limitations in case of leucopenia. EDTA whole blood (WB) has been proposed as the ideal material because of larger yields of DNA loads (8-10); and plasma $(\mathrm{PL})$ or serum (SE) were preferred for their easier sample processing and acceptable analytical performance (1114). This lack of consensus may be mainly attributed to a variety of PCR assays using different instruments, reagents, DNA extraction methods, and conducted in different centers, leading to interlaboratory variation and creating increasing clinical concern (15-18).

The aim of our study was to explore the best blood component for HCMV DNA surveillance after liver transplantation using one commercially available assay.

\section{Material and Methods}

\section{Patient samples}

A total of 168 sets of samples (each set consisted of WB, SE, and PL collected simultaneously from 1 patient) were gathered from 140 liver transplant recipients (133 adults and 7 infants) during their admission to the Ren $\mathrm{Ji}$ Hospital. The samples included 42 sets of serial specimens obtained during clinical follow-up. SE and PL were

Correspondence: C.M. Ying, Department of Clinical Laboratory, Ren Ji Hospital, School of Medicine, Shanghai Jiao Tong University, No. 160, Pujian Road, Pudong District, Shanghai 200127, China. Fax: +86-021-5839-4934. E-mail: ycmzh2012@163.com 
obtained from both non-anticoagulated and EDTA-anticoagulated blood after centrifugation at $926 \mathrm{~g}$ for $5 \mathrm{~min}$. All samples were stored at $-20 \pm 3^{\circ} \mathrm{C}$ before analysis.

\section{Sample analysis}

RTFQ-PCR was performed with a commercial HCMV kit (DaAn Gene Co., Ltd., China) using an ABI Prism 7500 Sequence Detection System (Applied Biosystems, USA). Since the kit does not provide reagents for WB DNA extraction, the WB samples were processed with a Tiangen Blood Genome Extraction kit (DP318, Tiangen Biotech Co., Ltd., China). The initial volume for DNA extraction from WB, SE, or PL was $100 \mu \mathrm{L}$. According to the manufacturer's protocol, PCR was carried out on 96well plates with a $45-\mu \mathrm{L}$ reaction volume containing $2 \mu \mathrm{L}$ DNA template, $3 \mu \mathrm{L}$ Taq polymerase, and $40 \mu \mathrm{L}$ PCR solution. The thermocycler procedure was as follows: initial denaturation at $93^{\circ} \mathrm{C}$ for $2 \mathrm{~min}$, followed by 10 cycles at $93^{\circ} \mathrm{C}$ for $45 \mathrm{~s}$ and $55^{\circ} \mathrm{C}$ for $60 \mathrm{~s} ; 30$ cycles at $93^{\circ} \mathrm{C}$ for $30 \mathrm{~s}$ and $55^{\circ} \mathrm{C}$ for $45 \mathrm{~s}$. Four calibrations (4-7 $\log _{10}$ copies $/ \mathrm{mL}$ ), one negative and two positive controls (weakly and highly positive, respectively) provided in the kit were all included in each run. The limit of detection (LOD) was $2.7 \log _{10}$ copies $/ \mathrm{mL}$ (i.e., 500 copies $/ \mathrm{mL}$ ) according to the manufacturer's operating manual. Positive results below the LOD were referred to as "weakly positive". The three comparative specimens (WB, SE, and PL) in each sample set were analyzed in parallel in the same PCR experiment to avoid interassay variation.

\section{Statistical analysis}

Chi-square and Fisher exact tests were carried out to compare qualitative results, and paired $t$-tests were used to analyze quantitative data. All calculations were done with the SPSS 14.0 program (SPSS Inc., USA). The statistical significance was set at $\mathrm{P}<0.05$.

\section{Results}

\section{Analysis of sensitivity}

As the qualitative results obtained with SE were identical to those for PL, they were combined into one

Table 1. Positive rate of HCMV DNA in whole blood (WB) and serum (SE)/plasma (PL).

\begin{tabular}{lccc}
\hline \multirow{2}{*}{ SE/PL } & \multicolumn{2}{c}{ WB } & Total \\
\cline { 2 - 3 } & \multicolumn{2}{c}{ Positive } & Negative \\
\hline Positive & $14(8.33 \%)$ & $0(0.00 \%)$ & $14(8.33 \%)^{*}$ \\
Negative & $14(8.33 \%)$ & $140(83.33 \%)$ & $154(91.67 \%)$ \\
Total & $28(16.67 \%)^{*}$ & $140(83.33 \%)$ & $168(100.00 \%)$ \\
\hline
\end{tabular}

Data are reported as number with percent in parentheses. ${ }^{*} \mathrm{P}<0.01$ (chi-square test). group for comparison with WB. As shown in Table 1, 14 $(8.33 \%)$ of the sample sets tested positive and 140 $(83.33 \%)$ tested negative with both WB and SE/PL. The remaining $14(8.33 \%)$ sets were WB-positive and SE/PLnegative. Low DNA levels were observed in these discrepant samples (median, $2.31 \log _{10}$ copies $/ \mathrm{mL}$; range, 1.44-3.06 $\log _{10}$ copies $\left./ \mathrm{mL}\right)$. Therefore, the positivity rate of WB $(16.67 \%)$ was much higher than that of SE/PL $(8.33 \%)\left(X^{2}=76.36, P<0.01\right)$.

\section{Comparison of HCMV DNA loads of WB, SE and PL samples}

In comparing DNA levels quantitatively, the 14 sets with PCR-positive results for all three materials were logtransformed and presented as DNA value ranges, quartile ranges, and median viral load (Figure 1). HCMV DNA loads observed with WB were significantly greater (paired $t$-test) than those observed in either SE (WB-SE mean logtransformed difference, $0.99 ; 95 \% \mathrm{Cl}=0.74-1.25$; $\mathrm{P}<0.0001$ ) or $\mathrm{PL}$ (WB-PL mean log-transformed difference, 1.37; $95 \% \mathrm{Cl}=1.07-1.66 ; \mathrm{P}<0.0001)$. No significant difference was found between the latter two materials (SE$\mathrm{PL}$ mean log-transformed difference, $0.37 ; 95 \% \mathrm{Cl}=0.19$ $0.55 ; P=0.6678)$.

\section{Sequential monitoring of HCMV DNA during clinical follow-up}

To study the viral kinetics during the course of active infection and antiviral therapy, we recorded two typical cases of successive DNA values during clinical follow-up.

Case 1. A 1-year-old infant, $\mathrm{HCMV} \operatorname{lgM}(-) / \operatorname{lgG}(-)$, received a living donor $[\mathrm{HCMV} \operatorname{lgM}(-) / \lg G(+)]$ liver transplant for congenital bile duct atresia. HCMV DNA

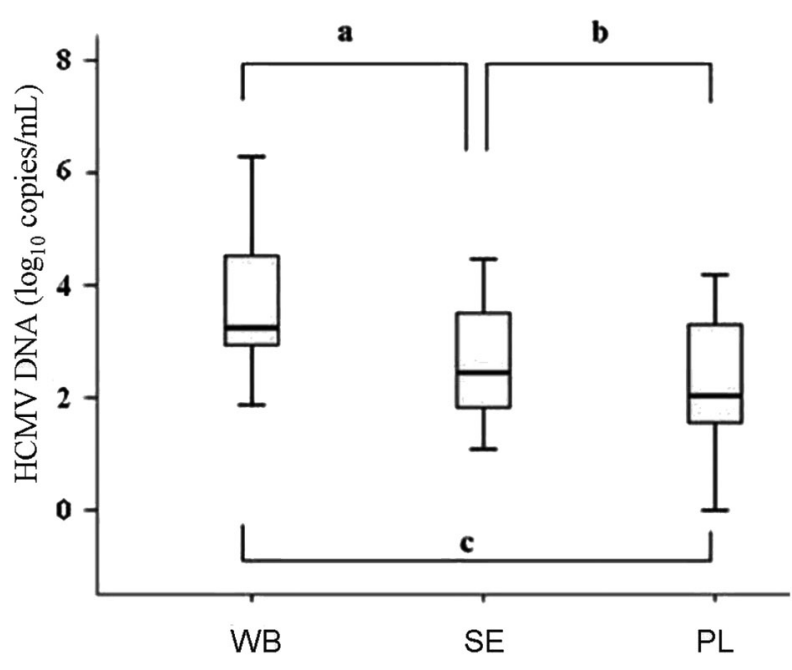

Figure 1. Quantitative comparison of HCMV DNA loads measured with WB, SE and PL. WB: whole blood: SE: serum; $\mathrm{PL}$ : plasma. Statistically significant differences $\left({ }^{\mathrm{a}} \mathrm{P}<0.0001\right.$, ${ }^{\mathrm{b}} \mathrm{P}=0.6678,{ }^{\mathrm{C}} \mathrm{P}<0.0001$, paired $t$-test). 
was assayed weekly post-transplantation to guide antiviral intervention. As shown in Figure 2A, low-level DNA values were detected in WB at the first $(2.76 \mathrm{e}+1$ copies $/ \mathrm{mL})$ and second $(7.90 \mathrm{e}+2$ copies $/ \mathrm{mL})$ weeks after transplantation, while the corresponding SE or $\mathrm{PL}$ samples indicated no viral replication. Afterwards, DNA values obtained with WB continued to rise to $3.34 \mathrm{e}+4$ copies $/ \mathrm{mL}$ at the third week, and high levels persisted $(4.16 \mathrm{e}+4$ copies $/ \mathrm{mL})$ after the fourth week. The measured viral loads sharply increased to $3.18 \mathrm{e}+3$ and $1.98 \mathrm{e}+3$ copies $/ \mathrm{mL}$ for SE and $\mathrm{PL}$, respectively, at the third week and persisted at the fourth week of follow-up $(5.09 e+3$ and $3.13 e+3$ copies $/ \mathrm{mL}$, for SE and PL, respectively). These values were both significantly lower than the WB counterparts obtained at the same times. Unfortunately, this young patient died of multiple organ failure on the 27th day after transplantation due to poor response to antiviral therapy.

Case 2. A 44-year-old male adult, HCMV $\operatorname{lgM}(-) /$ $\lg G(+)$, was evaluated for HCMV DNA because of abnormal liver function 1 month after standard orthotopic liver transplantation [donor: HCMV $\operatorname{lgM}(-) / \lg G(+)$ ]. Positive results were obtained in all three samples, and, accordingly, intravenous ganciclovir treatment $(250 \mathrm{mg}$, twice a day) was initiated immediately. Figure 2B summarizes DNA kinetics weekly during the course of treatment. In spite of similar declining rates and degrees, viral loads with WB appeared to persist for a longer period of time than the other two owing to its higher DNA levels at baseline.

The result of HCMV DNA surveillance in these two patients confirmed that the WB sample was positive earlier, yielded higher viral loads, and persisted positive longer during treatment compared with SE or PL.

\section{Discussion}

The high risk of HCMV activation after organ transplantation has attracted wide attention in clinical settings. Timely initiation of antiviral therapy and optimal management for infected patients rely mainly on early detection of viral activation as well as effective monitoring of therapeutic response.

Our data indicated that WB is more sensitive and yields higher DNA values than SE or PL (Table 1 and Figure 1). The biological features of HCMV infection may contribute to this finding. PBL is one of the usual sites that harbor HCMV in healthy adults with latent infection. When the virus replicates at a low level, such as at the early stage of reactivation or at the end of certain therapeutic regimens, only a few viruses are released into the serum or plasma. Thus, WB material that contains a large number of PBLs could appear to have higher viral loads than either SE or PL. This result is also consistent with some previously reported data (8-10). As for whether use of different DNA extraction kits for WB introduces
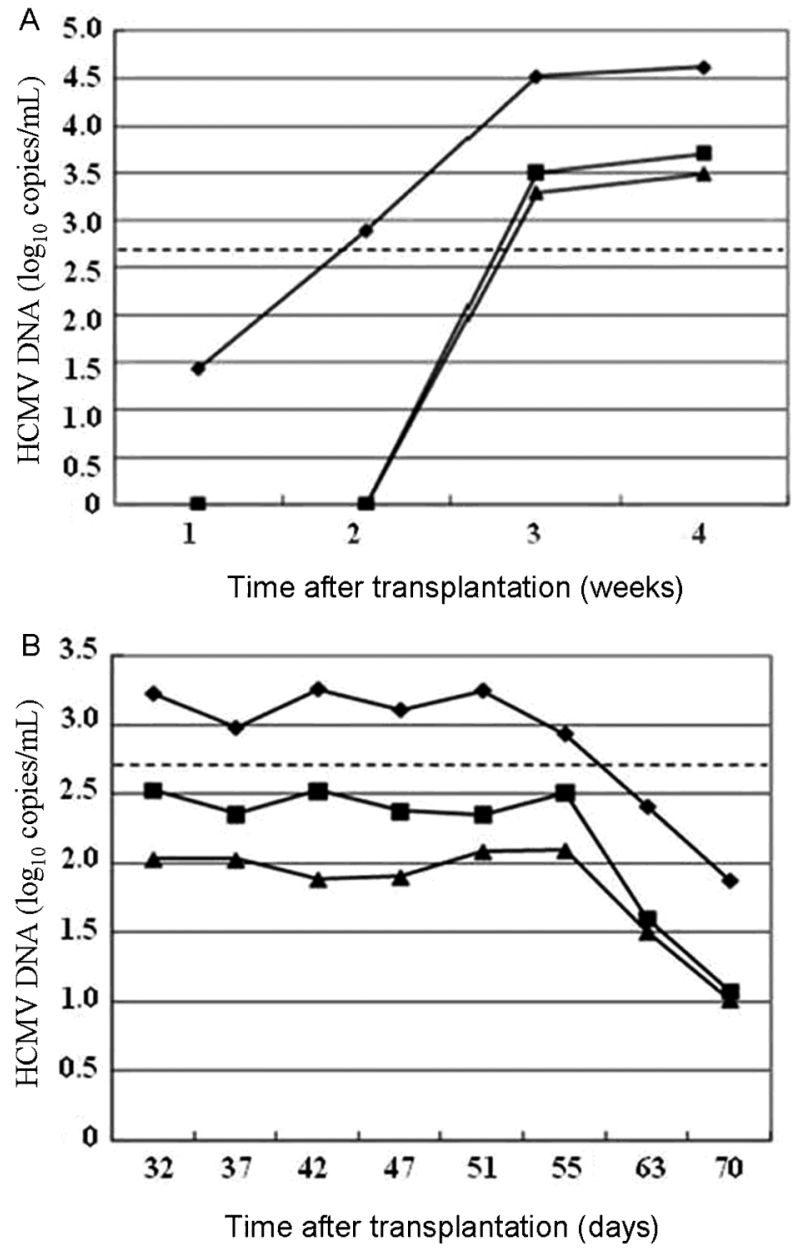

Figure 2. Monitoring of HCMV DNA for 2 clinical cases. A, 1year-old infant; $B$, 44-year-old male adult. Lozenges: whole blood; squares: serum; triangles: plasma. The dashed line indicates the limit of detection $\left(2.7 \log _{10}\right.$ copies $\left./ \mathrm{mL}\right)$.

technical bias, a previous report also demonstrated the superiority of WB when employing a common extraction method for both WB and PL (9). In this study, each set of comparative samples (i.e., WB, SE, and PL) were measured in parallel in one PCR experiment to maintain the same efficiency of amplification; thus, the PCR results could be reflective of original viral loads in corresponding specimens. Although extra steps required for DNA extraction from WB require additional time and expense, its capability to detect low-level HCMV DNA could provide clinicians with more detailed information about viral replication, which could help guide preemptive protocols as well as predict subsequent relapse following the completion of certain therapeutic regimens.

Since the kinetics of DNA replication is one of the important factors for predicting HCMV disease, monitoring HCMV DNA during follow-up has been proposed as a 
practical and efficient method to guide individualized therapy (19). Surveillance in clinical Case 1 revealed that WB samples have the advantage of showing earlier DNA positivity and more continuous viral dynamics when monitoring the development of HCMV disease. Moreover, Case 1 also suggests that a sharp increase in viral load during regular monitoring may be a strong signal of a burst of HCMV infection leading to deterioration of the patient. In contrast, Case 2 displayed gradually decreasing HCMV DNA in response to ganciclovir treatment. The downward slope of the DNA curves implied that the patient responded well to antiviral therapy and a good prognosis could be anticipated. Otherwise, persistence of high DNA levels during treatment might indicate drug failure for some reason (e.g., drug resistance or inappropriate dosages). To summarize, WB was superior to SE or PL for HCMV DNA surveillance because of earlier positivity and more continuous and complete recording of viral load dynamics.

With progress in transplant treatment, liver transplantation has been increasingly performed to cure congenital hepatobiliary diseases such as bile duct atresia. However, infant recipients are very susceptible to primary HCMV infection, which may easily be life threatening because of their immature immune system. In our study, infant patients showed significantly higher HCMV DNA and

\section{References}

1. Zhang $\mathrm{Y}$, Ji YH. Surveillance of HCMV DNA in transplant setting. Chin J Lab Med 2006; 29: 567-568.

2. Li M, Zhao WL, Ji YH, Peng YB, Zhi LM, Pan N. Monitoring of HCMV infection in bone marrow transplant recipients by quantitative PCR. Acta Univ Med Sec Shanghai 2002; 22: 143-145.

3. Gao LH, Zheng SS. Cytomegalovirus and chronic allograft rejection in liver transplantation. World $J$ Gastroenterol 2004; 10: 1857-1861.

4. Pellegrin I, Garrigue I, Ekouevi D, Couzi L, Merville P, Merel $P$, et al. New molecular assays to predict occurrence of cytomegalovirus disease in renal transplant recipients. $J$ Infect Dis 2000; 182: 36-42, doi: 10.1086/315688.

5. Boeckh M, Gallez-Hawkins GM, Myerson D, Zaia JA, Bowden RA. Plasma polymerase chain reaction for cytomegalovirus DNA after allogeneic marrow transplantation: comparison with polymerase chain reaction using peripheral blood leukocytes, pp65 antigenemia, and viral culture. Transplantation 1997; 64: 108-113, doi: 10.1097/00007890199707150-00020.

6. Zhang S, Zhou YH, Li L, Hu Y. Monitoring human cytomegalovirus infection with nested PCR: comparison of positive rates in plasma and leukocytes and with quantitative PCR. Virol J 2010; 7: 73, doi: 10.1186/1743-422X-7-73.

7. Li M, Ji YH, Peng YB, Zhi LM, Liu M, Huang T, et al. Comparison of two methods for earlier detection of active HCMV infection. Chin J Lab Med 2002; 25: 220-222.

8. Garrigue I, Boucher S, Couzi L, Caumont A, Dromer C, Neau-Cransac M, et al. Whole blood real-time quantitative $\lg \mathrm{M}$ and much lower IgG-positive rates than adults. Thus, more intensive monitoring (e.g., every 2-3 days instead of every week) is recommended, and antiviral intervention should be initiated without any delay in case of primary HCMV infection, even at low DNA levels, as discussed in a previous report by Kalpoe et al. (20). Nevertheless, the number of infant cases in this study was rather small and more cases are needed for further investigation of this issue in the near future.

In summary, this study demonstrated that WB compares favorably to SE or PL for HCMV DNA detection because of higher sensitivity and greater DNA yields. Monitoring DNA loads in WB samples by clinical follow-up offers a practical and effective approach to guide individualized therapy. Infant recipients who are usually at increased risk of primary HCMV infection need closer surveillance and more active intervention to improve survival rates after transplantation.

\section{Acknowledgments}

We thank Dr. Xiaosong Chen for reviewing clinical cases and Prof. Hongsheng Zhu for checking the manuscript. The research was supported by the Fund for Young Investigators (2010-2012) of Ren Ji Hospital, School of Medicine, Shanghai Jiao Tong University.

PCR for cytomegalovirus infection follow-up in transplant recipients. J Clin Virol 2006; 36: 72-75, doi: 10.1016/ j.jcv.2006.01.002.

9. Razonable RR, Brown RA, Wilson J, Groettum C, Kremers $\mathrm{W}$, Espy $\mathrm{M}$, et al. The clinical use of various blood compartments for cytomegalovirus (CMV) DNA quantitation in transplant recipients with CMV disease. Transplantation 2002; 73: 968-973, doi: 10.1097/00007890-20020327000025 .

10. Deback C, Fillet AM, Dhedin N, Barrou B, Varnous S, Najioullah F, et al. Monitoring of human cytomegalovirus infection in immunosuppressed patients using real-time PCR on whole blood. J Clin Virol 2007; 40: 173-179, doi: 10.1016/j.jcv.2007.08.014.

11. Zhao XT, Zhang Z, Zhang YR, Liu DM, Sun YY. Quantitative detection of CMV DNA by real-time PCR in transplant recipients. Chin J Lab Med 2006; 29: F438-F440.

12. Kaiser L, Perrin L, Chapuis B, Hadaya K, Kolarova L, Deffernez $C$, et al. Improved monitoring of cytomegalovirus infection after allogeneic hematopoietic stem cell transplantation by an ultrasensitive plasma DNA PCR assay. J Clin Microbiol 2002; 40: 4251-4255, doi: 10.1128/JCM.40.11.42514255.2002.

13. Yerly S, Perrin L, Van Delden C, Schaffer S, Thamm S, Wunderli W, et al. Cytomegalovirus quantification in plasma by an automated real-time PCR assay. J Clin Virol 2007; 38: 298-303, doi: 10.1016/j.jcv.2007.01.003.

14. Patel R, Smith TF, Espy M, Wiesner RH, Krom RA, Portela $D$, et al. Detection of cytomegalovirus DNA in sera of liver 
transplant recipients. J Clin Microbiol 1994; 32: 1431-1434.

15. Koidl C, Bozic M, Marth E, Kessler HH. Detection of CMV DNA: is EDTA whole blood superior to EDTA plasma? J Virol Methods 2008; 154: 210-212, doi: 10.1016/j.jviromet.2008.08.012.

16. Mengelle C, Mansuy JM, Da Silva I, Davrinche C, Izopet J. Comparison of 2 highly automated nucleic acid extraction systems for quantitation of human cytomegalovirus in whole blood. Diagn Microbiol Infect Dis 2011; 69: 161-166, doi: 10.1016/j.diagmicrobio.2010.08.011.

17. Gracia-Ahufinger I, Tormo N, Espigado I, Solano C, UrbanoIspizua A, Clari MA, et al. Differences in cytomegalovirus plasma viral loads measured in allogeneic hematopoietic stem cell transplant recipients using two commercial realtime PCR assays. J Clin Virol 2010; 48: 142-146, doi: 10. 1016/j.jcv.2010.03.015.

18. Von Muller L, Hampl W, Hinz J, Meisel H, Reip A,
Engelmann $\mathrm{E}$, et al. High variability between results of different in-house tests for cytomegalovirus (CMV) monitoring and a standardized quantitative plasma CMV PCR assay. J Clin Microbiol 2002; 40: 2285-2287, doi: 10.1128/ JCM.40.6.2285-2287.2002.

19. Emery VC, Sabin CA, Cope AV, Gor D, Hassan-Walker AF, Griffiths PD. Application of viral-load kinetics to identify patients who develop cytomegalovirus disease after transplantation. Lancet 2000; 355: 2032-2036, doi: 10.1016/ S0140-6736(00)02350-3.

20. Kalpoe JS, Kroes AC, de Jong MD, Schinkel J, de Brouwer $\mathrm{CS}$, Beersma MF, et al. Validation of clinical application of cytomegalovirus plasma DNA load measurement and definition of treatment criteria by analysis of correlation to antigen detection. J Clin Microbiol 2004; 42: 1498-1504, doi: 10.1128/JCM.42.4.1498-1504.2004. 